\title{
PRESAGIOS, AUGURIOS Y PORTENTOS DE LAS CONQUISTAS DE MESOAMÉRICA
}

\author{
UNA PERSPECTIVA COMPARADA
}

\author{
OMENS, AUGURIES AND PORTENTS OF \\ THE CONQUESTS OF MESOAMERICA \\ A COMPARATIVE PERSPECTIVE
}

Miguel Pastrana Flores

UNAM-Instituto de Investigaciones Históricas

micquetl@unam.mx

\begin{abstract}
This article proposes a historiographic comparative analysis of the tetzahuitl or omens, understood as the harbingers of the Spanish conquest in Purepecha and Nahuatl traditions, as registered by the Michoacan Relation and Floretine Codex, respectively. The article briefly revises the meaning of each omen consigned in the aforementioned works, then proceeds to make a general balance of each work in order to draw comparisons between the two. It proposes the existence of a common interpretative background of Mesoamerican tradition.
\end{abstract}

Keywords: tetzahuitl, omen, augury, conquest of Mexico, indigenous tradition historiography.

\section{Resumen}

Este artículo estudia, desde la perspectiva del análisis historiográfico comparativo, los presagios o tetzáhuitl, que se consideran anuncios de la conquista española en las tradiciones purépecha y náhuatl registradas en la Relación de Michoacán y en el Códice florentino respectivamente. Para ello se revisa brevemente el significado cada presagio consignado en las obras de referencia y luego se hace un balance general de cada obra y les compara. Se propone la existencia de un trasfondo común interpretativo de tradición mesoamericana.

Palabras clave: tetzáhuitl, presagio, augurio, conquista de México, historiografía de tradición indígena. 


\section{Un asunto misterioso'}

Es ampliamente conocido que en diversas obras historiográficas de tradición indígena mesoamericana se mencionan diversos presagios, augurios, prodigios y portentos a los que se atribuye ser anuncios de la conquista española. Entre estos escritos cabe destacar dos obras elaboradas por franciscanos: la Relación de Michoacán, atribuida a fray Jerónimo de Alcalá, y la Historia general de las cosas de Nueva España, de fray Bernardino de Sahagún, las cuales serán estudiadas en este trabajo desde la perspectiva de análisis historiográfico comparativo. En un primer momento, durante los siglos XVI al $X V I I I$, estos eventos portentosos del mundo indígena fueron generalmente aceptados como reales, o por lo menos como posibles, por los cronistas e historiadores hispanos y criollos, pues estaban en consonancia con su propia tradición religiosa e historiográfica tanto humanista como cristiana. Posteriormente, en los siglos XIX y XX, con el desarrollo de nuevas corrientes historiográficas los presagios fueron objeto de dudas y cuestionamientos, cuando no de franco escepticismo, mientras que en la actualidad se han convertido en objeto de estudio entre diversos especialistas (Pastrana, 2004: 15-21).

Desde la publicación en 1959 de Visión de los vencidos. Relaciones indígenas de la conquista, antología preparada por Miguel León-Portilla (2019), los relatos e historias de raigambre indígena sobre la Conquista empezaron a ser conocidos por un público amplio; es a finales del siglo $X X$ y en lo que va del XXI que, por diversas razones, entre las que cabe mencionar su relativa extensión, su difusión editorial e impacto académico, se ha puesto particular interés en los presagios nahuas de la conquista de Tenochtitlan. Grosso modo puede decirse que en la actualidad las principales posturas

1 Debo advertir al lector que, como ya me he ocupado en varias ocasiones de estos mismos temas o similares, retomo y sintetizo varios aspectos que en otros lugares he desarrollado más extensamente. Quien tenga interés en conocer con más detalle mis argumentos puede consultar la bibliografía referida. respecto del estudio de los presagios son las siguientes: una primera posición, que puede caracterizarse como escéptica, niega cualquier contenido propiamente indígena en estos presagios, y considera que se trata de adaptaciones o versiones tomadas de los clásicos grecolatinos o de textos bíblicos; tal es la postura sostenida, entre otros, por Felipe Fernández-Armesto (1992) y Guy Rozat (2010). Una segunda postura considera que los presagios están en consonancia con lo que se conoce de la cosmovisión mesoamericana y sostiene que el núcleo de los portentos está en el pensamiento indígena (si bien algunos autores admiten algún giro, matiz o trasfondo del cristianismo o de temas grecorromanos), como lo sustentan Miguel León-Portilla (1991, 1992), Michel Graulich (1992, 2014), Antonio Aimi (2009), Miguel Pastrana Flores (2004, 2014, 2020), Diana Magaloni (2003, 2016), Patrick Johansson (2013), Jaime Echeverría García (2018) y Guilhem Olivier (2019a, 2019b). Otros autores proponen una tercera posición, la cual pretende ser una especie de compromiso con las dos primeras, al aceptar un núcleo de tradición náhuatl que toma y adapta para sus propios fines modelos clásicos y bíblicos, como lo sostienen Hugh Thomas (1994: 68-71), Berenice Alcántara Rojas (2019a, 2019b) y Bernard Grunberg (2019). En lo que toca al ámbito purépecha y la Relación de Michoacán, la producción sobre el tema es mucho menor, pero se mantienen las dos propuestas principales, de quienes encuentran fuertes conexiones con la tradición mesoamericana (Pastrana, 1999), y de quienes sostienen que todos los presagios siguen modelos europeos con nulos elementos mesoamericanos (Morales y González, 2017).

En términos generales, quienes sostienen la segunda y tercera posturas han criticado a la primera y aportado argumentos en favor de la presencia de modelos y esquemas indígenas de raigambre mesoamericana en los relatos de los presagios, mientras que los representantes de la primera no han respondido a estas críticas; ejemplo de esta actitud es el caso de Arturo Morales y Juan 
Carlos González (2017) que no mencionan ningún trabajo de las otras posiciones, ni el artículo que específicamente aborda el tema en la Relación de Michoacán (Pastrana, 1999). Sobre los posibles modelos clásicos se volverá más adelante. Huelga señalar que aquí se ha hecho una síntesis por motivos expositivos de las diferentes posturas y que los distintos autores de las segunda y tercera propuestas mantienen importantes diferencias entre sí.

\section{Las obras en el contexto de la historiografía de tradición indígena}

\section{La historiografía de tradición indígena}

La historiografía de tradición indígena comprende el conjunto de obras historiográficas elaboradas por indígenas o por autores de otro origen que tratan de recopilar, comprender y asimilar el punto de vista de los grupos indios respecto de su pasado, tanto en el contexto mesoamericano como el colonial. Dicho de otra manera, la historiografía de tradición indígena es aquella que continúa, rescata, transmite o sigue, de manera parcial o amplia, los conceptos, las estructuras, los temas y los personajes de raigambre mesoamericana respecto del pasado indígena. Es necesario enfatizar que la tradición mesoamericana presenta procesos de cambio y adaptación en el tiempo novohispano; en ese sentido, las obras estudiadas son reflejo tanto de una tradición milenaria de registro, narración e interpretación del pasado como del contexto de su elaboración (Romero 2003, Pastrana, 2004, 2011, 2019a).

Como ya se dijo, este trabajo busca hacer un análisis comparativo de los presagios de la Conquista desde la perspectiva del análisis historiográfico entre dos tradiciones particulares dentro de la historiografía de tradición indígena, la purépecha según el grupo de élite uacúsecha en la Relación de Michoacán y la náhuatl de los informantes tlatelolcas de Sahagún. ${ }^{2}$ Puesto que el en-

2 Para la perspectiva de estudio se sugiere al lector consultar los siguientes autores: Edmundo O'Gorman foque de este trabajo es el análisis historiográfico, es adecuado abordar la presentación de las obras objeto de este estudio en el orden temporal en el que fueron elaboradas y no el de la cronología de los eventos de la conquista a los cuales se refieren, ya que el objetivo es estudiar los presagios en su contexto historiográfico y no estudiar el proceso político militar. ${ }^{3}$ En ese sentido, se verá primero la Relación de Michoacán, y luego la historia de la conquista recabada como Libro XII de la Historia general de Sahagún.

\section{La Relación de Michoacán}

La Relaçión de las ceremonias y rrictos $y$ poblaçión y governaçión de los yndios de la provinçia de Mechoacán, mejor conocida por el título abreviado y modernizado de Relación de Michoacán, fue escrita hacia 1540-1541 por un fraile de la orden de San Francisco. ${ }^{4}$ De acuerdo con la propia declaración del autor, éste se considera a sí mismo un intérprete de las narraciones de la élite uacúsecha: "esta escritura y relación presentan [...] los viejos desta cibdad de Mechuacan, y yo también en su nombre, no como autor, sino como intérprete dellos" (Relación, 1989, "prólogo": 33), especialmente en lo que atañe al desarrollo histórico del pueblo purépecha que ocupa la segunda de las tres partes que constituyen la Relación de Michoacán. Se trata de la versión castellana del relato de la historia del pueblo uacúsecha que efectuaba el principal sacerdote llamado petámuti, durante la fiesta de Equata cónsquaro. Por supuesto que ésta no es una traducción literal, sino más bien una versión parafrástica, con abundantes aclaraciones, comentarios

(1999, 2009), José Gaos (1967), Ramón Iglesia (1986). 3 Para quien desee un marco de referencia sobre los eventos militares, véanse Benedict Warren (1989), José Luis Martínez (1990) y Thomas (1994).

4 Aunque la propuesta de Benedict Warren (2001) de identificar al autor con fray Jerónimo de Alcalá ha gozado de amplia aceptación entre muchos estudiosos, y sin duda es la hipótesis mejor fundamentada, esto no es totalmente seguro; por ello, en este trabajo se seguirá con la denominación tradicional. 
y adecuaciones por parte del fraile menor, como él mismo lo indica:

Las sentencias van sacadas al propio de su estilo de hablar, y yo pienso de ser notado mucho en esto, mas como fiel intérprete no he querido mudar de su manera de decir, por no corromper sus sentencias y en su interpretación, he guardado esto, sino ha sido algunas sentencias y muy pocas que quedarían faltas diminutas si no se añadiese algo, y otras sentencias van declaradas, porque las entiendan mejor los lectores (Relación, 1989, "prólogo": 33).

La cuestión de que tanto logró el franciscano su propósito de ser fiel intérprete del discurso de sus informantes uacúsechas es motivo de análisis y discusión (Roskamp, 1998; García Quintana, 2003; Espejel, 2004).

La narración del petámuti, tal y como la podemos conocer gracias a la Relación, era una historia ejemplar, en el sentido que se proponía hacer evidentes formas de ser y comportamientos individuales y colectivos que se consideraban idóneos, y que deberían servir de modelo para la conducta de los diversos grupos sociales, especialmente para la élite de mando y el linaje gobernante, de donde salía el mandatario principal, conocido como cazonci, tal como lo expresa el franciscano: "Todo este capítulo pasado tenía el cazonci en mucha reverencia y hacía al sacerdote que sabía esta historia, que se la contase muchas veces, y decía que este capítulo era doctrina de los señores y que era aviso que había dado Taríacuri a todos ellos" (Relación, 1989, 2a parte, cap. XXII: 136).

El relato de la conquista hispana se ubica al final de la tercera parte de la obra, y los presagios ocupan específicamente el capítulo XIX que habla de "los agüeros que tuvo esta gente y sueños, antes que viniesen los españoles a esta provincia" (Relación, 1989, 3a parte, cap. XIX: 246), lo cual indica con certeza que en el momento de ser recogidos e incorporados al conjunto de la Relación de Michoacán los presagios aún no formaban parte del discurso oficial que oralmente contaba el petamuti. Al pa- recer, la fuente principal de la narración de la conquista española de Michoacán es la información proporcionada por antiguos sacerdotes y especialmente por don Pedro Panza, gobernador indígena de Pátzcuaro y antiguo alto dignatario de la administración purépecha al momento del contacto con los hispanos. En ambos casos, los informantes suelen ostentarse como testigos oculares o como cercanos a quienes presenciaron estos eventos (Relación, 1989, 3a parte, cap. XIX, XX: 248, 254; López Serralengue, 1965: 171).

\section{Historia de la conquista española}

Por otra parte, entre los años 1550 y 1555 el franciscano fray Bernardino de Sahagún recogió de labios de informantes indígenas de Tlatelolco una historia de la conquista española en lengua náhuatl que, con ayuda de sus antiguos alumnos del colegio de Santa Cruz convertidos en cercanos colaboradores, transcribió en caracteres latinos. Tal como se ha conservado el texto náhuatl de la conquista en el Libro XII del Códice florentino carece de título, Sahagún se limita a describir brevemente su contenido: "El dozeno libro Tracta de cómo los españoles conquistaron a la ciudad de México", "Libro doze. De la conquista de la Nueva España, que es la ciudad de México" (Sahagún, 1990, v. II: 949); por otra parte, el que hoy sea el doceno de los libros de la obra sahaguntina es un mero accidente; por esos motivos, y para distinguirlo de la versión castellana del Florentino y de la reelaboración de la obra emprendida en 1585, así como para destacar su carácter de obra independiente he optado por designarla como historia de la conquista.

Posteriormente, entre 1558 y 1560, Sahagún inició en Tepepulco los trabajos de recopilación sistemática de textos sobre el mundo náhuatl, que a la postre y muchos años después, llegaron a constituir lo que hoy conocemos como Historia general de las cosas de Nueva España. Hacia 1565 la historia de la conquista se incorporó a este proyecto $\mathrm{y}$, después de varios reordenamientos, se ubicó en su estructura como Li- 
bro XII. Más adelante, entre 1576 y 1577, fray Bernardino y sus colaboradores indígenas dispusieron el texto castellano de la Historia general y, por ende, el de la conquista. En 1577 el manuscrito bilingüe náhuatl-español de la Historia general fue enviado a España, de donde pasó a Florencia a finales de 1587, donde actualmente reposa en la Biblioteca Medicea Laurenciana; esta obra es generalmente conocida por el nombre de Códice florentino. En 1585, ya en el ocaso de su vida, Sahagún emprendió el reordenamiento y rescate de varios de sus trabajos, produciendo, entre otros escritos, la Relación de la conquista de esta Nueva España, como la contaron los soldados indios que se hallaron presentes. Convirtiéndose en lengua española, llana e inteligible, y bien enmendada en este año de 1585 (en adelante Relación de la conquista de 1585), la cual corrige la primitiva versión de la historia de la conquista recabada, como ya se indicó, hacia los años de 1550 a 1555 (Pastrana, 2015: 8586, s.f.; Nicolau, 1952; Bustamante García, 1990; León-Portilla, 1999).

Para esclarecer el asunto de la autoría de la historia de la conquista, el punto de partida son las referencias expresas de fray Bernandino anotadas tanto en la versión castellana del Libro XII de la Historia general como en la Relación de 1585, pues el texto náhuatl del Códice florentino no tiene indicaciones explícitas de autoría. En el prólogo al Libro XII Sahagún dice que "se escrivió en tiempo que eran vivos los que se hallaron en la misma conquista, y ellos dieron esta relación, personas principales y de buen juizio, y que se tiene por cierto que dixeron toda verdad" (Sahagún, 1990, L. XII, Al lector; v. II: 949). En el mismo título de la Relación de la conquista de 1585 se dice que es una obra escrita "como la contaron los soldados indios que se hallaron presentes", y en el prólogo "Al lector" dice: "Los que me ayudaron en esta escriptura fueron viejos principales y muy entendidos en todas las cosas, así de la idolatría como de la república y oficios della, y también que se hallaron presentes en la guerra cuando se conquistó esta ciudad" (Sahagún, s.f.) En todo el texto abundan las referencias al origen tlatelolca de los informantes. Se trata, pues, de indígenas de alto rango, antiguos pillis, dignatarios y guerreros, testigos de vista de los hechos que relatan, con alta preparación intelectual y conocimiento de las tradiciones e instituciones nahuas de la antigüedad. Los tetzáhuitl de la conquista están consignados principalmente en el capítulo 1, titulado "De las señales y pronósticos que aparecieron antes que los españoles veniesen a esta tierra ni huviese noticia de ellos" (Sahagún, 1990, L. XII, cap. 1, v. II: 949). ${ }^{5}$

Recientemente, Berenice Alcántara Rojas (2019a y 2019b) ha propuesto que esta obra es de la autoría de los colaboradores nahuas de Sahagún, los cuales la redactaron hacia 1565 con base en testimonios indígenas recabados con anterioridad; sin embargo, no aporta referencias concretas ni plantea huellas textuales de tal actividad. Por otra parte, en las obras en las que Sahagún interviene como editor o autor, ya sea con modificaciones, comentarios, adecuaciones e incluso reescribiéndolas por completo, lo hace de manera expresa, así lo señala en el libro de los Coloquios y doctrina cristiana con que los doce frailes de San Francisco, enviados por el papa Adriano VI y por el emperador Carlos V, convirtieron a los indios de la Nueva España, el cual en 1564 pasó a "conuertirse en lengua mexicana bien congrua y limada: la qual [escritura en náhuatl] se boluió y limó en este colegio de Santa Cruz del Tlatilulco este sobre dicho año [1564] con los colegiales más habiles y entendidos en lengua mexicana y en la lengua latina que hasta agora se an en el dicho colegio criado [...] Limóse asimismo con quatro viejos muy pláticos, entendidos ansí en su lengua como en todas sus antigüedades." (Sahagún, 1986: 75) Una situación similar se menciona en el

5 En Relación de la conquista de 1585, el título del primer capítulo es "De las señales y pronósticos que aparecieron en esta Nueva España antes que se supiese la fama de la gente española ni de su venida, por espacio de un año", Sahagún (s.f., cap. 1). También se refieren algunos tetzáhuit/ de la conquista en el libro VIII de la Historia general (Sahagún, 1990, L. VIII, cap., v. II, p. 558-559). 
caso del llamado Exercicio quotidiano, al final del manuscrito se asienta: "Este exercicio hallé entre los indios, no se quien le hizo ni quien se le dio [a los indios] tenía muchas faltas e incongruidades mas con verdad se puede dezir que se hizo de nuevo, que no se enmendó. Este año de 1574". (Sahagún, 1993: 202). También lo señala explícitamente en el caso de la Relación de la conquista de 1585:

este año de mil quinientos ochenta y cinco enmendé este libro, y por eso va escripto en tres columnas. La primera es el lenguaje indiano ansí tosco como ellos lo pronunciaron, y se escribió entre los otros libros. La segunda columna es enmienda de la primera ansí en vocablos como en sentencias. La tercera columna está en romance, sacado según las enmiendas de la segunda columna. (Sahagún s.f.: Al lector; Pastrana 2015, s.f.).

Por lo tanto, puede afirmarse que hasta el momento no hay elementos suficientes para hablar de una intervención mayor de fray Bernardino y sus colegiales en la historia de la conquista en náhuatl; tal como este texto se encuentra en el Códice florentino, el principal trabajo de edición es la división en capítulos.

Así, como resultado del proceso de elaboración de esta compleja obra existen tres versiones fundamentales, las cuales están estrechamente vinculadas entre sí y al mismo tiempo presentan diferencias importantes para el análisis historiográfico y su aprovechamiento para la reconstrucción histórica. En primer término, está la historia de la conquista escrita en náhuatl desde la perspectiva tlatelolca, elaborada antes de 1550 y recopilada por Sahagún y sus colaboradores entre 1550 y 1555; en segundo término, está la versión castellana escrita por fray Bernardino y concluida en 1576-1578; y, finalmente, la versión ampliamente revisada y corregida hecha en 1585. Para este trabajo se usará preferentemente el texto náhuatl de 1550-1555 que está en el Códice florentino, pero siempre cotejado con la versión castellana de Sahagún en la Historia general y la versión de la Relación de la conquista de 1585.

Desde otra perspectiva hay que agregar que las obras que son objeto de este estudio pueden ubicarse en dos categorías diferentes dentro del concepto de historiografía de tradición indígena. Por un lado, la historia de la conquista, que está compilada en el Códice florentino, puede concebirse como parte de la continuidad de las antiguas formas de historiografía mesoamericanas, las cuales estaban en proceso de cambio y adaptación al ámbito colonial; por otro lado, los franciscanos fray Bernardino de Sahagún y el autor de la Relación de Michoacán, sin duda son buenos representantes de la recopilación y rescate de la historiografía de tradición indígena (Pastrana, 2011: s.f.). En su carácter de obras historiográficas estos trabajos manifiestan la comprensión y explicación narrativa de la conquista española por parte de las élites indígenas uacúsecha y tlatelolca, la cual fue recogida por los franciscanos y sus colaboradores, y no es el registro contemporáneo de los acontecimientos de ese proceso militar y político.

\section{Tetzáhutil, presagio, agüero}

\section{El tetzáhuitl}

Uno de los aspectos más notables en el estudio de los presagios es la identificación y análisis del concepto de tetzáhuitl como la categoría náhuatl usada en las obras del centro de México, no sólo para la historiografía de la conquista española sino para el caso de la caída de Tula y en la vida cotidiana (Pastrana 1999, 2004, 2014, 2019a; Johansson, 2013; Echeverría, 2018). En términos generales puede decirse que tetzáhuitl es una cierta forma de manifestación de los dioses nahuas en el ámbito de lo humano, que rompe el orden habitual y cotidiano del mundo para anunciar y provocar acontecimientos futuros generalmente de carácter negativo; por ello suelen causar temor, espanto y asombro, como lo registra fray Alonso de Molina: "tetzáhuitl: maravilla, cosa escandalosa, o espantosa, o cosa 
de agüero, agüero, pecado grande" (Molina, 2014: 345). Los variados vocablos que usa Molina no corresponden por completo al sentido del vocablo náhuatl, como lo expresó Hernando Ruiz de Alarcón en su Tratado de las supersticiones:

Lo que en España llaman agüeros, en mexicano llaman tetzáhuitl, si bien el vocablo mexicano suena algo más que el castellano, porque dice agüero, pronóstico, portento o prodigio, que pronostica algún mal presente o venidero; todo lo dicho comprende el nombre tetzáhuitl (Ruiz, 1988, tratado 1, cap. IX: 70).

Los tetzáhuitl acontecen de igual manera en el transcurso del ciclo de vida de los más humildes macehuales, o en los cambios políticos, sociales e históricos de mayor envergadura y trascendencia. Los tetzáhuit/ son parte fundamental de la dinámica de la historia indígena, pues son, al mismo tiempo, prodigios, anuncios funestos del porvenir y causas de los eventos que anuncian. En sus manifestaciones concretas pueden ser un objeto, un fenómeno, un ser o un comportamiento, lo relevante es que se manifieste como algo portentoso, inusitado o anómalo, siempre es una ruptura o alteración del orden cotidiano o habitual del mundo (Pastrana 2004, 2014, 2020; López Austin, 2019).

Para el ámbito purépecha no se cuentan con textos en dicha lengua donde se manejen con claridad los conceptos indígenas respecto de estos fenómenos. Sin embargo, en los vocabularios y diccionarios tanto coloniales como modernos se encuentran algunas menciones de interés; así, fray Maturino Gilberti en su Vocabulario de la lengua de Mechuacan consigna los siguientes vocablos: agorar, tomar agüero: vintsiyaquareni; agorero que las declara: huariatamiyuri, vintsiaquareta ayanguhpensti; agorería: huriata miyuqua; agüero: vintsiyame; agüero: Vintsiyaquarequa, vintsiyamequa; monstruo en naturaleza: vintsiyamequan has; vintsiyaquareta ayanguhpentsani: declarar los milagros, invenciones, agüeros y hechicerías (Gilberti, 1556). Por su parte, Pablo Velásquez Gallardo registra las siguientes voces: uinsájpiri: animal agorero; uitsíajpiri: agorero de buena fe; uintsikurhini: dar vuelta, el dar vueltas alrededor; uintsítani terórukua: dar vuelta en una esquina (Velásquez, 1978). Con base en estos vocablos, y al hecho que vintsiyamequan designe tanto al monstruo y como al agüero, cuya mutua raíz indica girar o doblar, Roberto Martínez propone que posiblemente vintsiyamequa signifique algo cercano a "volteado". 6

Como se dijo arriba, en otros lugares he tratado con cierta amplitud el significado de los tetzáhuitl, presagios y agüeros de las obras estudiadas en el marco de la tradición mesoamericana (Pastrana 1999, 2004, 2014); en este sentido, en este apartado sólo se hará un resumen de las tradiciones particulares purépecha y náhuatl como referente general a su estudio comparado, para ello tomo en cuenta las valiosas aportaciones de otros investigadores. Se seguirá el orden elaboración de las obras.

\section{Los presagios de la Relación de Michoacán}

El primero de los agüeros de la conquista de tradición purépecha en la Relación de Michoacán es la destrucción de templos sin causa aparente, pues durante cuatro años continuos "se les hendían sus cúes, desde lo alto hasta bajo, y que lo[s] tornaban a cerrar, y luego se tornaba[n] a hender" (Relación 1989, 3a parte, cap. XIX: 246). En Mesoamérica los templos eran puntos de contacto entre el mundo de los seres humanos y el de los dioses; por ejemplo, con respecto a los templos de Pátzcuaro se decía que "en este susodicho lugar, tuvieron sus antepasados, en mucha veneración y dijeron que aquí fue el asiento de su dios Curícaueri. Y decía el caçoci pasado, que en este lugar, y no en otro ninguno, estaba la puerta del cielo por donde descendía y subían sus dioses" (Relación 2011, 2a parte, cap. VII: 37), además de ser los edificios públicos más relevantes que eran ejes en la construcción de los centros urbanos, por ello su destrucción

6 Martínez, comunicación personal. Agradezco la gentileza de Roberto Martínez al compartir esta valiosa información. 
prefiguraba la ruptura en la comunicación entre seres humanos y los entes divinos, así como el trastocamiento del orden sagrado y político que daba cohesión a la sociedad.

El segundo presagio fue la aparición de "dos grandes cometas en el cielo y pensaban que sus dioses habían de conquistar o destruir algún pueblo y que ellos habían de ir a destruirle" (Relación 1989, 3a parte, cap. XIX: 248). Significativamente se dice que al principio pensaron que ellos serían los conquistadores, con lo cual se precisa el sentido tradicional de conquista militar de este agüero entre los purépechas. Al igual que el resto del mundo, en Mesoamérica los cometas y otros fenómenos celestes y astronómicos eran objeto de atenta observación y registro, pues se les consideraba manifestaciones de la voluntad de los dioses. ${ }^{7}$ Por ejemplo, los antiguos nahuas consideraban que estos fenómenos anunciaban la muerte de los gobernantes, la guerra, el hambre y las enfermedades (Sahagún, 1990, L. VII, cap. IV, v. II: 542-543).

El tercer presagio es un sueño recurrente de un sacerdote purépecha en el cual llegaba gente con animales "que él no conocía" que eran caballos, esta gente entraba a las habitaciones de los sacerdotes "dormían allí con sus caballos, y que traían muchas gallinas que se ensuciaban en sus cúes [...] donde ellos hacían su oración y tenían su vela" (Relación 1989, 3aparte, cap. XIX: 248).

El sentido general es claro, el arribo de las fuerzas militares españoles que usan los recintos dedicados al culto de los dioses como simple dormitorio y que las aves ensucien los templos remite una de las afrentas más grandes que podría recibir un grupo mesoamericano, la profanación y la desacralización de sus templos, como lo refiere, entre otras fuentes la Historia de los mexicanos por sus pinturas (Tena, 2002, cap. XVIII, pp. 62-63). Este presagio prefigura el fin del culto público indígena, la desarticulación de las antiguas instituciones religiosas

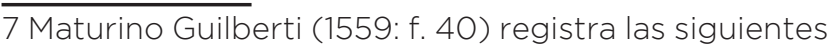
entradas: "Cometa encendida sirauata angantsi", "cometa pequeña que parece caer hozqua quanicuqua", "cometa grande que parece correr hancheranapu cipapu". y con ello una ruptura en la comunicación entre los dioses y los purépechas.

El cuarto presagio es la epidemia de viruela que introdujeron los españoles y se difundió entre muchos pueblos mesoamericanos en 1520, de la cual "murió infinidad de gente y muchos señores, y cámaras de sangre de las viruelas y sarampión" (Relación, 1989, 3a parte, cap. XIX: 248). En la cosmovisión mesoamericana una de las principales causas de enfermedad era la intervención divina.

En este caso no hay una mención específica de su significado, sino más bien se muestra su efecto, la muerte entre los diferentes grupos de la sociedad. Llama la atención que se mencione también el sarampión, cuando la primera epidemia de esta enfermedad ocurrió en 1531, 11 años después de la primera; puede pensarse que quizás a pesar de la distancia temporal los purépechas asimilaron en un solo evento catastrófico los efectos epidémicos de la conquista. ${ }^{8}$

El quinto presagio es, sin duda, el más complejo de toda la serie de la Relación de Michoacán. Una de las mujeres de Uiqixco, señor de Ucareo, fue visitada por la diosa Cuerauaperi y poseída por ella. En ese estado alterado de conciencia fue llevada por el dios Curicaueri, bajo la forma de su nahual de águila blanca, hasta el monte Xanoata hucatzio, donde se encontraban reunidas todas las deidades purépechas.

Una vez ahí, la mujer escuchó a las divinidades decir que habían sido creados nuevos hombres que llegarían a sus tierras. Los dioses protestaron ante esta notica alegando que se rompía un antiguo orden de alternancia divina, el cual fue establecido antes de la salida del sol que alumbra la era actual, pues:

8 Mendieta (1980, L. IV, cap. XXXVI: 514), para el ámbito del centro de México dice: "La segunda pestilencia les vino también de nuevo por parte de los españoles, once años después de las viruelas, y esta fue de sarampión [...] de que murieron muchos, aunque no tantos como de las viruelas [...] Á este sarampión llamaron ellos tepiton záhuatl, que quiere decir pequeña lepra"; Gilberti (fol. 139) registra: "pestilencia teparipamangarata", "pestilencial cosa teparipamangarataesti". 
la verdad no fue esta determinación al principio, questaba ordenado que no anduviésemos dos dioses juntos antes que viniese la luz, porque no nos matásemos, y perdiésemos la deidad, y estaba ordenado entonces, que de una vez sosegase la tierra, que no se volviese dos veces, y que para siempre se había de estar ansí, que no se había de mudar. Esto teníamos concertado todos los dioses antes que viniese la luz (Relación, 1989, 3a parte, cap. XIX: 251).

Este acuerdo de alternancia divina era parte de la estructura misma del tiempo y su presencia en la tierra implicaba un cierto predominio de sus atributos y de los pueblos a ellos vinculados (López Austin, 2015: 79-87). Por ello, la sola idea de alterar este orden primordial llenó de estupor a las propias deidades, pues es una ruptura en la estructura temporal de todo el cosmos purépecha $y$, por ende, de la vida de los seres humanos, se trata de una fractura en el tiempo y en el orden mundano; por ello, no había manera de saber o prever con algún grado de certeza lo que ocurriría en el mundo, pues "ya son criados otros hombres nuevamente y otra vez de nuevo han de venir a las tierras" (Relación, 1989, 3a parte, cap. XIX: 250). Lo que implica también la novedad radical de la presencia hispana "son criados otros hombres nuevamente", pues al no ser parte del orden del mundo conocido su sola llegada implica el fin de una era y el inicio de un nuevo orden.

Los efectos serán devastadores, los dioses tendrán que retirarse de las tierras purépechas, "vosotros los dioses primogénitos y de la man[o] izquierda, íos todos a vuestras casas", también se acabarán los antiguos rituales "no han de parescer más cués, ni fogones, ni se levantarán más humos”, pues "todo ha de quedar desierto, porque ya vienen otros hombres a la tierra". De esta manera se insinúa el fin del culto público mesoamericano, la implantación de una sola forma de religiosidad y un solo gobierno para todos los grupos indígenas, ya "el cantar será todo uno, y que no habrá muchos cantares como teníamos: mas uno sólo por todos los términos de la tierra". Al final del concilio divino los dioses "empezaron a limpiarse las lágrimas y encomendaron a la mujer informar de todo lo que había escuchado al cazonci Zuangua" (Relación, 1989, 3a parte, cap. XIX: 251).

A su regreso, la mujer llegó a un templo de la diosa Cuerauáperi, donde fue recibida y alimentada ritualmente con sangre humana, pues aún mostraba las señales de un estado de posesión divina, pues "cuando aquella diosa Cuerauáperi tomaba alguna persona, que entraba en ella [...] comía sangre" (Relación, 1989, 3a parte, cap. XIX: 252). Los sacerdotes informaron al señor de Ucareo, quien manifestó su temor e incertidumbre ante el porvenir: "¿dónde han de ir los señores questán? ¿quiénes nos han de conquistar? ¿han de venir los mexicanos o los otomíes a conquistarnos, o los chichimecas? Dice que todo el reino ha de estar solo y desierto" (Relación, 2011, 3a parte, cap. XIX: 237). Finalmente, los sacerdotes acudieron a informar del agüero al cazonci.

El sentido general de este presagio es el de una ruptura del orden temporal y de la secuencia de presencias divinas en el cosmos, el abandono de los dioses del ámbito de los hombres, lo cual es anunciado principalmente por las deidades Cuerauáperi ${ }^{9}$ y Curicaueri, ${ }^{10}$ un principio femenino vinculado al inicio mismo del cosmos y un principio masculino ligado al poder terrenal de los uacúsechas; por ello anuncian el fin de un orden de cosas, el término de la religión indígena, así como la pérdida del poder de los gobernantes y la muerte de quienes ostenten el rango de cazonci.

9 Cuerauaperi, "la que desata en su vientre a seres animados racionales” (Monzón, 2005: 150-151, 154), era una de las deidades fundamentales del panteón purépecha, pues los demás dioses fueron paridos por ella (Martínez González, 2013: 81), lo que la acerca a Teteoinan, "madre de los dioses", y a Toci, "nuestra abuela", entre los nahuas.

10 Curicauerin o Curicuaueri, dios principal de los uacúsechas, deidad de carácter solar y bélico; su nombre significa "fuego que sale ardiendo" o "el que sale haciendo fuego", "El representante de Curicuaueri en la tierra es el 'cazonci' o rey a través del cual los 'súbditos' reciben las disposiciones de todo lo relacionado con la guerra" (Monzón, 2005: 142-143). En muchos aspectos es similar a Huitzilopochtli entre los mexicas. 
El sexto presagio lo refiere el propio cazonci Zuangua justo después de conocer el presagio anterior al anunciar la pérdida del poder de los gobernantes purépechas, su propia muerte y que el hijo que lo sucedería en el mando gobernaría poco tiempo. Al respecto dijo: "Que de nosotros es la pérdida del señorío, que somos señores, y no de nosotros solos, mas empero de todas las provincias; yo no lo oiré, que primero moriré y no será luego, porque aún estaré algunos días [...] Aquí están mis hijos [...] y no sé quién será el que señalare por rey, nuestro dios Curicaueri [...] y el pobre no será mucho tiempo señor, porque será maltratado, pobre de la gente baja" (Relación, 1989, 3a parte, cap. XIX: 253).

Sin duda, este anuncio está presentado como una prefiguración de los hechos posteriores a la llegada de los españoles, particularmente la pérdida del poder de los gobernantes purépechas y el trato infamante que recibió el cazonci Tzintzicha Tangaxoan, hijo mayor y sucesor de Zuangua, por parte de los castellanos.

El séptimo presagio es referido por el cazonci al contar el rapto de un pescador por un dios que se manifestó como un nahual de caimán "y llevóle a su casa" debajo de agua; ahí le encomendó enviar este mensaje a Zuangua, "que ya se ha dado sentencia, que ya son hombres y ya son engendrados los que han de morir en la tierra por todos los términos: esto les dirás al rey" (Relación, 1989, 3a parte, cap. XIX: 254). Es el segundo caso de personas comunes que son transportadas por los dioses purépechas en forma de nahuales; en el primero, una mujer es llevada por un águila por un ámbito aéreo; en el segundo, un hombre es llevado por un caimán por un ámbito acuático, lo cual quizás se trata de un aspecto dual; sin embargo, hay que tener en cuenta que el dualismo no parece ser muy relevante entre los antiguos purépechas. Este portento tiene el sentido evidente de anunciar la muerte de los gobernantes purépechas y la pérdida del poder por parte de la élite de mando.

El octavo presagio es referido por Zuangua después del regreso de los emisarios que envió en respuesta a la embajada mexica en la que les proponían una alianza para enfrentar a los castellanos. Es la aparición de los dioses Tiripemencha en Cuyacan ante una anciana pobre que repartía agua. En su mensaje acusan a los gobernantes de no atender el culto religioso, pues "no son sabios los señores de Cuyacan ni se acuerdan de traer leña para los dioses", por lo cual "se han enojado los dioses engendradores", y por ello abandonarán paulatinamente los asentamientos purépechas hasta llegar a su "primer morada en Bayameo". Además, los gobernantes "ya no tienen las cabezas consigo", esto es que serán capturados en la guerra y decapitados ritualmente (Relación, 1989, 3a parte, cap. XXI: 260-261). Los Tiripemencha son hermanos de Curicaueri $y$, al igual que éste, están ligados al poder político, a la autoridad del cazonci y a sus obligaciones rituales (Relación, 2011, 3a parte, cap. XVIII: 229)."

En síntesis, hay faltas de orden religioso que provocan el abandono de los dioses, la pérdida del poder del cazonci, la guerra y la muerte ritual de los señores purépechas. También es posible, como propone Roberto Martínez, que la alusión a que los gobernantes "ya no tienen las cabezas consigo" no sólo se refiera la muerte ritual, sino también al fin de las diferencias jerárquicas de la sociedad en el contexto colonial, así como la paulatina pauperización de la antigua élite, e implique una pérdida de cualidades humanas, pues "se borraría la frontera entre humanidad y animalidad" (Martínez González, 2013: 44-45).

El noveno presagio implica una ruptura del orden de la naturaleza, también es contado por el cazonci, pues "los cerezos, aun hasta los chiquitos, habían de tener fruto y los magueyes pequeños habían de echar mástiles, y las niñas que se habían de empreñar antes que perdiesen la niñez; esto es lo que decían los viejos, y ya se cumple" (Relación, 1989, 3a parte, cap. XXI: 260). Por

11 Dadas las semejanzas entre Curicaueri y Huitzilopochtli cabe pensar en una correspondencia entre sus hermanos, los Tiripemencha y los Cetzon Huitznahuaque, "cuatrocientos de la región de las espinas", las estrellas meridionales. 
una parte, la ruptura del orden de lo natural afecta a toda la sociedad y trastoca su propia estructura, especialmente la precoz madurez sexual de las niñas; por otra parte, alude al regreso a un estado de cosas caótico, similar al inicio del mundo, "un regreso a los orígenes", similar al que propone Echeverría para los tetzáhuitl de la caída de Tula (Echeverría, 2018: 305).

Si se reúnen los sentidos principales de todos presagios de la Relación de Michoacán, se encuentra que anuncian un cambio radical del orden del mundo, un posible regreso a un mundo indiferenciado primordial, el fin de la alternancia de dioses en las tierras purépechas, el fin de los ritos y ceremonias, el fin de poder político, la muerte de gobernantes, la degradación de la élite, así como guerra, hambre y enfermedades. Cabe destacar que estos anuncios están conformes a la lógica misma de la Relación, a lo que conoce de la cosmovisión purépecha y hay muchos símiles con lo que se sabe del resto de Mesoamérica.

También es notable la novedad de los hispanos, pues son "nuevamente creados". Lo anterior está en consonancia con el regreso a un mundo primordial indiferenciado, similar al momento en que fueron creados los diferentes tipos de seres mundanos, entre ellos los grupos humanos.

Hay que resaltar que algunos de estos presagios son públicos con sentidos evidentes para quienes los observan, o los dioses declaran abiertamente su significado; otros agüeros se manifiestan individualmente, pero también su sentido es expresado claramente por las deidades.

Todos los mensajes se concentran en la figura del cazonci, ya sea porque a él están dirigidos o porque le atañen como máxima autoridad política y ritual. Parece que el significado profundo está ligado a la idea de fin de mundo, al término de una forma de vida y un orden sacro, y no tanto en anunciar las características del orden que lo sustituirá; es decir, se enfatiza el fin del mundo purépecha y no la instauración del nuevo orden colonial.

\section{Los Tetzáhutil en la tradición de Tlate/olco}

En lo que toca a la historia de la conquista tlatelolca recogida por Sahagún y sus colaboradores, la narración comienza justamente con ocho tetzáhuitl en el primer capítulo del Libro XII y de la Relación de 1585, y que son los que de manera tradicional se consideran. Adicionalmente a ellos hay dos más en otros capítulos.

El primer tetzáhuitl de la conquista mencionado ha podido identificarse como un mixpantli o mixpanitl "estandarte de nubes" (Pastrana, 2004), descrito como tlemiahuatl, "espiga de fuego", que ocurrió durante el año 12 calli, fenómeno que fue percibido por toda la sociedad y fue motivo de desconcierto y temor colectivo. Así se describe:

un tetzáhuitl primero apareció en el cielo, estuvo chispeando, así como una espiga de fuego, así como la aurora. Parecía que se erguía como si estuviera punzando el cielo. Ancha del asiento, delgada de la cabeza. Bien en medio del cielo, bien se erguía su centro llegando al cielo, bien estaba alcanzando el centro del cielo. Así se veía, en el oriente, hacia acá se levantaba, así salía, a la media noche, parecía como que amenazaba a amanecer. En amaneciendo, el sol la hacía desaparecer, cuando emergía [...] Y cuando aparecía, la gente hacía ruido, se golpeaba los labios, se escandalizaba, expresaba su angustia (Sahagún, 1979, L. XII, cap. I; en Alcántara Rojas, 2019a: 58).

El sentido general de este fenómeno es referido por fray Andrés de Olmos, quien en su Arte de la lengua mexicana, al tocar las "formas metafóricas de hablar", bajo la expresión "tener alguno pobreza o hambre", refiere el siguiente texto náhuatl: "Auh tepan moquetza in mixpanitl, in tlemiauatl, iztic cecec quiztoc icnoyutl quiztoc" (Olmos, 2002: 192), "y sobre la gente se levanta el estandarte de nubes, la espiga de fuego, arroja frío, helada, arroja miseria". ${ }^{12}$ El significado es claro, el tetzáhuitl anuncia la llega-

12 Siempre que se transcriba el texto náhuatl debe entenderse que la traducción es mía. 
da de bajas temperaturas y heladas, incluso con las consecuentes malas cosechas, las cuales provocarán pobreza y hambre generalizadas, en otras palabras, un desastre alimentario, económico y social.

El segundo tetzáhuitl es el incendio espontáneo del templo de Huitzilopochtli: "De inmediato la gente hace ruido, dice. 'Mexicanos, vengan de prisa, hay que apagarlo, vuestros cántaros...'. Pero cuando se le echaba agua, se le quería apagar, sólo mucho más se encendía. No pudo apagarse, todo se quemó" (L. XII, cap., I; trad. Alcántara Rojas, 2019a: 60). El sentido es claro, el tetzáhuitl alude a uno de los signos y ritos de conquista militar más comunes de Mesoamérica, el incendio del templo del dios patrón de la población derrotada; en segundo término se menciona el agua, que lejos de apagar las llamas las incrementa. Alude a unos de los difrasismos de la guerra, atl tlachinolli, "agua lo quemado"; de esta manera el significado de este presagio es el anunciar una guerra que culminará con la conquista de Tenochtitlan; en términos religiosos implica el fin del periodo de predominio de Huitzilopochtli y los mexicas, así como el comienzo de un nuevo ciclo.

El tercer tetzáhuitl es el incendio del templo de Tzonmolco dedicado al dios Xiuhtecuhtli provocado por la caída de un rayo: "No llovía recio, sólo llovía rocío, así que se tuvo por tetzáhuitl. Así se decía: 'sólo fue golpe de sol', 'tampoco se oyó el trueno'”, (Sahagún, 1979, L. XII, cap, I; en Alcántara Rojas, 2019a: 60).

El sentido de este presagio se aclara cuando se considera que Xiuhtecuhtli es una deidad relacionada a los cambios de ciclo y las transformaciones. También es uno de los dioses vinculados a la transmisión del poder, y en la fiesta que se le dedicaba en la veintena de Izcalli la imagen del dios era ataviada como el tlahtoani en turno (Sahagún, 2000, L. I, cap. XIII: v. I, 83). Así, este portento prefigura un cambio de ciclo, afectaciones al fundamento sacro del mando político y males para el gobernante.

El cuarto tetzáhuitl es la aparición de un fenómeno celeste, quizás un meteoroide o un cometa, "cuando todavía había sol un fuego cayó, se partió en tres [...] Algo así como brasas va lloviznando, lejos va yendo su cola, lejos va llegando su cola” (Sahagún, 1979, L. XII, cap, I; en Alcántara Rojas, 2019a: 62). En este caso, las fuentes señalan que este tipo de fenómenos eran considerados tlatocatetzáhuitl, "tetzáhuitl de mando", que específicamente anunciaba la muerte de gobernantes, la guerra y la hambruna (Sahagún, 1969: 148-149, 151).

El quinto tetzáhuitl es el comportamiento inusual de las aguas del lago de Tetzcoco: "hirvió el agua, no la hizo hervir el viento. Fue como si burbujeara, como si burbujeara, como si burbujeara ruidosamente, muy lejos llegaba, por eso se levantó y alcanzó los cimientos de las casas, y se destruyeron, se derrumbaron las casas" (Sahagún, 1979, L. XII, cap, I; en Alcántara Rojas, 2019a: 63). Como lo señala Graulich (2014: 245), es interesante que fray Gerónimo de Mendieta ubique temporalmente este evento en 1499, esto es, en tiempos del tlahtoani Ahuítzotl, lo que quizás aluda a la inundación de Tenochtitlan provocada bajo su mandatado por el mal manejo del famoso manantial Acuecuéxatl (Mendieta, 1980, L. III, cap. II: 178). Por otra parte, esos borbotones en el lago se mencionan para el sumidero de Pantitlan, donde las barcas eran absorbidas por un remolino y también para las apariciones del ahuítzotl, animal acuático vinculado a Tláloc que ahogaba a las personas arrastrándolas al fondo de los lagos (Espinosa, 1996: 7274; Sahagún, 1969: 107-111). Además, la destrucción de casas hasta los cimentos donde saliera agua era una pena infamante en el caso de delitos graves e implicaba la ejecución de toda la familia inmediata del infractor. Así, este tetzáhuitl anuncia la inundación de la ciudad, el fin de muchos linajes y la pérdida de vidas en el lago; es posible, como propone Magaloni (2016), que aluda a la guerra lacustre emprendida por los famosos 13 bergantines de Cortés. Si efectivamente este tetzáhuit/ se refiere a la inundación producida por el manejo erróneo de las aguas del manantial Acuecuéxatl por parte de Ahuítzotl, entonces también implicaría 
un señalamiento a las terribles consecuencias que pueden acarrear las malas decisiones del tlahtoani en turno.

El sexto tetzáhuitl es uno de los más conocidos: "de noche se oyeron voces muchas veces, como de una mujer que angustiaba y con Iloro decía... 'iOh, hijos míos, que ya ha llegado vuestra destrucción!' Y otras veces decía: 'iOh, hijos míos, del todo nos vamos ya!' Y otras veces decía: 'iOh, hijos míos! ¿dónde os llevaré porque no os acabéis de perder? Ya vuestra destrucción ha llegado' (Sahagún, s.f.: cap. 1). Las imágenes del Códice florentino que acompañan este presagio remiten a una diosa madre de la cual se decía: "Cioacoatl tequanj yoan tetzaujtI tetetzaujani, icnoiutl qujteittitia: ca mitoaia, victli mecapalli qujtemacaia, ic temotlaia [...] ioal chocatinenca tecoiouhtinenca, noiautetzaujtl catca” (Sahagún 1979, L. I, cap. VI: f. 2v.-3r.), "Cihuacóatl: devoradora de personas y tetzáhuitl, da tetzáhuitl a la gente, les muestra la miseria, porque se decía que daba a la gente el huictli, el mecapal, por eso bajaba el trabajo agrícola [...] de noche anda llorando, anda bramando, está gritando el tetzáhuitl". Al igual que otros dioses nahuas, Cihuacóatl tiene la condición de ser ella misma un tetzáhuitl, un portento que causa miedo, que anuncia y provoca con su sola presencia cosas funestas para el porvenir, como la muerte, la miseria, el trabajo agotador de los simples macehuales y el castigo divino, en este caso anuncia la destrucción de Tenochtitlan.

El séptimo tetzáhuitl es el más complejo de la serie del Códice florentino, por eso se citará en extenso:

una vez, cuando la gente del agua estaba pescando con redes o cazando con redes, agarraron un ave cenicienta, semejante a una grulla. Enseguida fueron a hacérsela ver a Motecuhzoma, en el Tlillancalmécac. Declinaba el sol, pero aún era de día. Encima de [la grulla] se extendía algo así como un espejo, circular como malacate, redondo, como si estuviera perforado en el centro. Allí se aparecía el cielo, las estrellas, el mamalhuaztli. Y Motecuhzoma mucho lo tuvo por tetzáhuit/ cuando vio las estrellas y el mamalhuaztli. Y, una segunda vez miró encima del ave, un poco más allá vio como si algunas personas vinieran vestidas para la guerra, las cargaban venados. Y luego llamó a los tlaciuhque, a los tlamatinime, les dijo: "No saben ustedes lo que yo acabo de ver, a algunos que venían como derechos". Ya iban a contestarle, cuando miraron, y desapareció, no [pudieron] decir nada más (Sahagún, 1979, L. XII, cap. I; en Alcántara Rojas, 2019a: 67).13

En este tetzáhuit/ se yuxtaponen diversos elementos que por sí mismos son anuncios misteriosos y aciagos. Se destacarán varios puntos: el ave misma, el espejo, las estrellas que son vistas, los guerreros observados y el lugar donde se presencia el enjambre de portentos. En el libro XI de la Historia general se mencionan aves maravillosas que son anuncios de desgracias, particularmente el cuatézcatl "cabeza de espejo" que, como su nombre lo indica, tenía un espejo redondo en la cabeza que con seguridad la relaciona con Tezcatlipoca, "el humo del espejo", uno de los dioses relacionados con la transmisión del poder político. Así, "tenían por mal agüero cuando esta ave aparecía. Dezían que era señal de guerra. Y el que la caça en el espejo vía si había de ser cautivo de guerra, porque en el espejo vía si havía de ser cativo en la guerra" (Sahagún, 1990, L. XI, cap.2, par 3, v. II: 806). Los espejos mismos eran objetos de propiedades sacras, pues a través de ellos era posible atisbar el mundo de los dioses, al tiempo que estos podían ver por ellos el ámbito de los seres humanos. Es, pues, un portal o punto de comunicación entre el ámbito mundano y el ultraterreno.

Motecuhzoma observó en el espejo dos imágenes, unas estrellas y unos guerreros. La segunda visión tiene un sentido claro, se trata de las huestes españolas que atacarán Tlatelolco y Tenochtitlan. Las estrellas observadas reciben el nombre de mamalhuaztli, las cuales conforman el cinturón y la espada de la constelación de Orión; estas estrellas son por sí mismas un tetzáhuit/ que anuncia eventos aciagos. Fray Andrés

13 He modificado la traducción en algunos puntos. 
Olmos las incluye en una expresión náhuatl que implica "Tener alguno pobreza o hambre", "Xulutl mapantoc, chayauhtoc techan, xiuhcóatl, mamalhuaztli tepan quizá, tetech, motlalia, tepan mochihua" (Olmos, 2002: 192), "se visten como sirvientes, están caídas las casas de la gente, la xiuhcóatl, el mamalhuaztli salen sobre la gente, se asientan sobre la gente, se forman sobre la gente". También está mencionado en la expresión "Da Dios hambre o enfermedad", "Xiuhcoatl, mamalhuaztli tepan quimotlaxilia, tepan quimochiuilia yn Dios" (Olmos, 2002: 190). "La xiuhcóatl, el mamalhuaztli son arrojados sobre la gente, sobre la gente los hace Dios".

Además, el mamalhuaztli es el nombre de un instrumento para producir fuego, conocido como barrenador de fuego. Este instrumento tenía usos prácticos y rituales, en estos últimos destaca su uso en ceremonias importantes, como la inauguración de aposentos de gobernantes, de templos, el inicio de las guerras y, sobre todo, en la ceremonia del fuego nuevo, en la cual se marcaba el fin de un ciclo cósmico y el inicio de otro cada 52 años. En el momento de la ceremonia se apagaban todos los fuegos y sobre un hombre sacrificado se usaba un mamalhuaztli, ritual para obtener un nuevo fuego y repartirlo a toda la población. Por eso es posible que la vista del mamalhuazltli celeste anunciara a Motecuhzoma el fin de un ciclo cósmico con sus repercusiones terrenales, el fin de una época, la de los mexicas. Por si fuera poco, el mamalhuaztli, junto con la xiuhcóatl "serpiente turquesa o de fuego", que es el rayo, ambas se mencionan como las armas por antonomasia de Huitzilopochlti, dios guerrero y conquistador patrón de Tenochtitlan y Tlatelolco (Sahagún, 1990, L. XII, cap. XXVIII), lo cual parece apuntalar tanto el anuncio de la derrota mexica en una próxima guerra como un cambio de ciclo celeste y terrestre.

El lugar donde se resguarda Motecuhzoma y ve los anuncios también es relevante, se trata de Tlillancalmécac, "el calmécac del lugar de lo negro"; es una escuela reservada a la educación de lo más granado de la élite tenochca, un calmécac al cuidado del sacerdocio de la diosa Cihuacóatl, quien "da tetzáhuitl a la gente", deidad que anuncia y causa graves acontecimientos. El Tlillancalmécac es parte de un conjunto de edificios sagrados vinculados a Cihuacóatl, que incluía su propio templo, el Tlillancalco, "en la casa de lo negro", y el Coacalco, "en la casa del conjunto", dependencia inaugurada por Motecuhzoma Xocoyotzin donde se tenían reunidas, como si estuvieran presas, las efigies sagradas de los dioses patronos de los pueblos sometidos (Pastrana, 2019b). Así, Motecuhzoma busca refugio en una escuela de élite dedicada a la deidad que da tetzáhuit/ a las personas, buscando una respuesta entre sus sacerdotes a las ominosas señales que se ciernen sobre la ciudad y su persona, pero cuando acude a los tlaciuhque, especialistas en el conocimiento de lo oculto "los cuales dezían, sabían y alcançavan lo que su dios disponía y determinava de las cosas" (Sahagún, 1990, L. X, cap. 29, par. 6, v. II, p. 758), a los tlamatinime, "los que conocen las cosas", los sabios por antonomasia (León-Portilla, 2018: 100-110); antes que ellos puedan siquiera acercarse al ave, ésta desaparece misteriosamente; así, el conocimiento tradicional sobre las señales divinas y quienes lo detentan resultan inaccesibles o inútiles para Motecuhzoma. De esta manera, este tetzáhuitl, anuncia un cambio de ciclo temporal, tanto cósmico como terrenal, así como la guerra, el hambre, trabajos para la población, la muerte de los gobernantes. Además, el marco institucional en el cual se interpretan los tetzáhuitl, las dependencias vinculadas a la diosa Cihuacóatl, Tlillancalco, Tlillancalmécac y Coacalco, así como los especialistas en el conocimiento de las señales divinas, los sacerdotes, los tlacihuque y los tlamatinime, resultan totalmente incapaces de orientar al tlahtoani.

El octavo tetzáhuit/ se refiere a lo siguiente: "muchas veces se descubrían hombres, hombres monstruosos, con dos cabezas y un solo cuerpo; allá los llevaban al Tlillancalmécac. Allí los veía Moctezuma [sic]; los veía y enseguida desaparecían" (Sahagún, 1979, L. XII, cap, I; trad. Alcántara Rojas: 69).

Graulich (2014: 246) ha propuesto que los 
seres con dos cabezas estaban relacionados con Xólotl, deidad que es un desdoblamiento de Quetzalcóatl. Ambos son patrones de los seres monstruosos y los gemelos. Cabe recordar que los humanos con discapacidades o anormalidades eran objeto de interés por parte de los mexicas, algunos estaban al servicio de tlahtoani; además, junto a la llamada Casa de las Fieras había un edificio donde se concentraban a estas personas (Cortés, 1993: 245-246; Torquemada, 197577: v. I, pp. 314, 408). También, eran usados como emisarios y ofrendas para entrar en contacto con los seres sobrehumanos que resguardaban pasos o portales a sitios sagrados, como es el caso de la cueva del Cincalco "en la casa del grano de maíz" que presidía Huemac (Alvarado Tezozómoc, 1997: cap. 105: 439-440; Durán, 1984: Historia, cap. LXVII; v. II: 493). Por todo esto, es posible que este presagio anunciara un trastocamiento del orden del mundo, de un cierto regreso al caos primordial del cosmos, donde los seres aún no estaban del todo definidos ni diferenciados entre sí, lo cual sucede en situaciones de cambios bruscos y radicales, lo que recuerda lo referido en la Relación de Michoacán respecto de la maduración sexual precoz de plantas y personas.

Estas alteraciones del orden natural, especialmente la aparición de seres extraños o monstruos como marcadores de cambios políticos, han sido señaladas y comentadas por Echeverría (2018; véase también Martínez González, 2013: 44-45). ${ }^{14}$ Este tetzáhuitl, además anunciar problemas en la comunicación con las entidades sobrehumanas que controlaban los lugares que eran pajes para llegar al mundo de lo sacro y su desaparición en el Tlillancalmécac, reitera la incapacidad de los especialistas religiosos para dar respuestas a Motecuhzoma.

14 En tanto trastocamiento del orden mundano con vínculos a un retorno a un tiempo primordial, también recuerda a la tradición quiché del fin de la era de la gente de madera, cuando los animales domésticos y los utensilios de cocina cobran conciencia y voluntad para atacarlos (Popol Wuj, 2012: 17-20).
El noveno tetzáhuitl está en el capítulo XIII y ocurre mientras el ejército de la alianza hispano-tlaxcalteca se dirige a Tenochtitlan. Motecuhzoma envía magos por segunda ocasión para tratar de dañar a los extraños y detener su avance, pero antes de llegar a ellos, en el camino a Tlalmanalco, se les aparece Tezcatlipoca bajo la apariencia de un borracho vestido a la usanza de Chalco, quien los increpa:

¿Para qué vosotros volvéis de nuevo acá? ¿Qué es lo que Motecuhzoma pretende hacer para vuestro remedio contra los españoles? Tarde ha vuelto sobre sí, que ya está determinado de quitarle su reino y todo cuanto tiene y toda su honra por las grandes tiranías que ha cometido contra sus vasallos; no ha regido como señor, sino como tirano y traidor (Sahagún, s.f., cap. XIII).

Los magos se percatan que se trata de Tezcatlipoca y proceden a levantar un altar y honrarlo, pero el dios los desprecia y vuelve a increparlos: "Por demás habéis venido. Nunca más haré cuenta de México. Para siempre os dexo. Lo que queréis no se puede hacer. Volveos y mirad hacia México" (Sahagún, 1990, L. XII, cap. XIII, v. II: 967). Voltean y tienen una visión de la ciudad destruida por la guerra: "vieron arder en vivas llamas, así los templos como las demás iglesias y todos los colegios y todas las casas de principales y de gente baja, y allí se les representó la guerra de la destruicción de México". El impacto de la prefiguración de la ciudad destruida fue tremendo: "se les derritió el corazón como si fuera de cera y se les hizo un ñudo en las gargantas y quedaron como mudos y sin lengua que no podían hablar" (Sahagún, s.f., cap. XIII).

Tezcatlipoca es un dios relacionado con el otorgamiento y la pérdida del poder de los gobernantes. Sus manifestaciones de embriaguez o promoviéndola están relacionadas con la caída de las ciudades, como es en el caso de las destrucción de Tula cuando emborracha a Quetzalcóatl (Olivier, 2019b); su disfraz de chalca es, sin duda, un señalamiento de las afrentas cometidas por 
los mexicas a los pueblos sometidos y que prefiguran el apoyo que muchos de ellos brindaron a los castellanos; también es claro sobre las faltas morales atribuidas de Motecuhzoma como gobernante y el anuncio del fin de su periodo de gobierno; finalmente la prefiguración de la destrucción de la ciudad en la guerra que se avecina es una señal particularmente ominosa. Por eso no debe sorprender la reacción anímica de los enviados, se les va el corazón, se les derrite; esto es, su centro de conciencia está totalmente afectado, ya no tienen control de sus emociones, uno de los ideales fundamentales de la educación mexica y una de las obligaciones principales de los gobernantes.

El décimo y último tetzáhuitl ocurre en los momentos finales del asedio a las ciudades lacustres:

Y se vino a aparecer una como grande llama. Cuando anocheció llovía, era cual rocío la lluvia. En ese tiempo se mostró aquel fuego. Se dejó ver, apareció cual si viniera del cielo. Era como un remolino; se movía haciendo giros, andaba haciendo espirales. Iba como echando chispas, cual si restallaran brasas. Unas grandes, otras chicas, otras como leve chispa. Como si un tubo de metal estuviera al fuego, muchos ruidos hacía, retumbaba, chisporroteaba (Sahagún, 1956, L. XII, cap. XXXIX: 160).

No es del todo claro el simbolismo de este último tetzáhuitl, quizás sea otra alusión al difrasismo atl tlachinolli, "agua lo quemado", la guerra, pero como anuncio del término de ella, y con ello el último punto en la derrota de los mexicas y en el cumplimiento de los otros tetzáhuitl. Es posible que eso explique que ante este prodigio los defensores de la ciudad lacustre guardaron silencio, "Ios mexicanos no dieron grita, como soelen hacer en tales visiones; todos cayaron por miedo de los enemigos" (Sahagún, 1990, L. XII, cap. 39, v. II: 1000). En ese momento, los otrora poderosos guerreros mexicas temían más a las armas de los enemigos que al propio portento. En su conjunto, los tetzáhuitl de la obra sahaguntina aluden a un cambio de ciclo celeste y terrestre, al abandono de los dioses, a la guerra y a la destrucción de Tenochtitlan y Tlatelolco, así como a la muerte de gobernantes y la pérdida del poder de Motecuhzoma; también a heladas, hambre y enfermedades. El contexto institucional de templos y especialistas en la comunicación con los dioses se manifiesta ineficaz de ofrecer respuestas ante las inquietudes que surgen por la sucesión ominosa de los tetzáhuitl.

\section{Vasos comunicantes}

Una primera comparación de los tetzáhuitl de la Conquista en las obras estudiadas siguiendo puntualmente sus manifestaciones concretas arroja, en un primer vistazo, que no hay muchos puntos de contacto. Salvo la mención de cometas y los daños en los templos, no hay correspondencia directa. Es más: en el segundo caso hay notables diferencias.

En la Relación se infiere que todos o la mayoría de los templos fueron los afectados, mientras que la historia tlatelolca son específicamente los templos de Huitzilopochtli y de Xiuhtecuhtli; así, en primera instancia se podría pensar que no comparten modelos o referentes comunes (cuadro 1).

Sin embargo, si se indaga sobre el conjunto de significados acordes con el contexto cultural de tradición mesoamericana, más allá de las manifestaciones concretas, la comparación arroja resultados muy distintos.

Los significados que comparten tanto la Relación de Michoacán como los textos de los informantes de Sahagún se pueden articular en unos ejes básicos. Primero, aspectos temporales, especialmente la noción de fin de ciclo, de ruptura temporal. Es particularmente elocuente y dramática la visión de la Relación de Michoacán que habla de la quiebra del orden de presencias divinas en el mundo, o la equiparación de la conquista con cambio de ciclo de 52 años entre los nahuas.

En ambas tradiciones existe la noción de un cierto retorno al caos primordial, lo que parece reforzado por Diego Muñoz Camar- 
go en su Descripción de Tlaxcala (2000: 215): "Todas estas señales [...] les pronosticaban su fin y acabamiento, porque decían que había de venir el fin y que todo el mundo se había de acabar y consumir, y que habían de ser creadas otras nuevas gentes y venir otros nuevos habitadores del mundo". Otro eje fundamental es la noción del abandono de los dioses. Esto es muy importante porque son deidades de primer nivel en culto sagrado y en las relaciones con los grupos de poder.

Curicaueri lo dice abiertamente, mientras que Huitzilopochtli simplemente calla, y son otras deidades las que anuncian su salida, destacan las diosas madres Cuerauáperi y Cihuacóatl; en Tezcatlipoca el señalamiento es particularmente claro: "para siempre os dejo"; la principal diferencia estriba en que las deidades purépechas se ven obligadas a hacerlo por una alteración del orden temporal, en tanto que sus contrapartes nahuas lo hacen, aparentemente, por su propia voluntad y como reacción a las faltas éticas de Motecuhzoma.

Otro eje es la guerra, con las muertes que conlleva y, en caso de los mexicas, la prefiguración de la ruina de las ciudades lacustres, elemento que no se encuentra entre los purépechas porque sus ciudades fueron conquistadas, en un primer momento, de manera pacífica, en tanto que Tenochtitlan $\mathrm{y}$ Tlatelolco fueron sometidas a sangre $\mathrm{y}$ fuego.

Otro eje es la pérdida del poder de los máximos gobernantes, el cazonci y el tlahtoani, así como de los grupos que presidían, los uacúsechas y los mexicas, que dejarán de ser pueblos hegemónicos y conquistadores para ser grupos sometidos.

También se destaca el fin de las formas religiosas públicas, el término de las ceremonias, ritos y símbolos dedicados a los dioses. Hay que resaltar que estos ejes compartidos por uacúsechas y tlatelolcas ponen énfasis en el fin de una era, de una forma de vida.

Resaltan lo que pierden como grupos de poder, pero realmente no hay referencias directas en los presagios de la conquista a las características de los castellanos y su cultura, nada que aluda directamente a la introducción del cristianismo. Claro que es parte del contexto y se manifiesta en otras partes de los respectivos relatos, pero prácticamente nada se dice, alude o implica de manera directa en los presagios mismos. Esto es un indicio más que el núcleo del significado de los presagios de la conquista está en la tradición mesoamericana y no en los elementos cristianos o grecorromanos. ${ }^{15}$

De esta forma se puede proponer la presencia de ciertas nociones e ideas de tradición mesoamericana que son comunes a ambas obras historiográficas de la conquista, aunque sus manifestaciones específicas sean muy distintas entre sí. Dicho de otra forma, hay en el fondo de ambas narraciones ciertos elementos estructurales similares atribuibles a la tradición cultural mesoamericana común, aunque la selección y narración específica de los distintos presagios difieran mucho entre sí.

15 En el libro VIII de la Historia general sí hay un presagio de clara inspiración cristiana. Se trata de la supuesta resurrección de la princesa Papatzin. Significativamente no se menciona en la historia de la conquista del Libro XII, lo que indica que no es parte de la versión tlatelolca del conflicto, sino una versión piadosa aislada, sin ser parte de una narrativa histórica. En las obras del ciclo de la Crónica X, como la Historia de la Indias de fray Diego Durán (1967) y la Crónica mexicana de Hernando de Alvarado Tezozómoc (1997), sí hay referencias claras al cristianismo, sobre todo en la Historia del dominico (Pastrana, 2004). 


\section{Cuadro 1}

\section{Comparación entre la Relación de Michoacán y la Historia de la conquista}

\begin{tabular}{lll}
\hline \multicolumn{1}{c}{ Relación de Michoacán } & \multicolumn{1}{c}{ Libro XII } & Comentarios \\
\hline 1. Caen las lajas de los templos. & $\begin{array}{l}2^{\circ} \text { Incendio del templo de } \\
\text { Huitzilopochtli; 3a Destrucción } \\
\text { del templo de Xiuhtecuhtli }\end{array}$ & $\begin{array}{l}\text { Semejanza parcial } \\
\text { en la forma y el } \\
\text { significado. }\end{array}$ \\
$\begin{array}{lll}4^{\circ} \text { Cometa o meteoroide que se } \\
\text { divide en tres partes. }\end{array}$ & $\begin{array}{l}\text { Semejanza parcial } \\
\text { en la forma y el } \\
\text { significado. }\end{array}$
\end{tabular}

3. Un sacerdote sueña que personas extrañas montadas en venados ocupan las habitaciones sacerdotales, las aves ensucian las habitaciones.

Sin correspondencia.

4. Epidemias de viruelas y sarampión.

Se menciona la epidemia de viruela, pero no como tetzáhuitl.

5. Posesión divina y viaje de una mujer a una reunión de los dioses.

Sin correspondencia.

6. El cazonci Zuangua anuncia su propia muerte.

Motecuhzoma presiente su

muerte. No se le designa

tetzáhuitl.

7. Dios como nahual de caimán habla con hombre común.

Sin correspondencia.

$\begin{array}{lll}\text { 8. Aparición de los dioses } & \text { 9a Aparición de Tezcatlipoca } & \text { Muy diferentes. } \\ \text { Tirípimencha. } & \text { como chalca ebrio. }\end{array}$

9. Maduración sexual precoz de la naturaleza y de las niñas.

Aparición de seres deformes.

Semejanza parcial en el significado.

\section{Cuadro 2 \\ Síntesis de los significados de los distintos presagios}

\begin{tabular}{|c|c|c|}
\hline Sintesis & $\begin{array}{l}\text { Relación de } \\
\text { Michoacán }\end{array}$ & $\begin{array}{l}\text { Informantes de } \\
\text { Sahagún }\end{array}$ \\
\hline $\begin{array}{l}\text { Aspectos temporales. Ruptura del orden temporal. } \\
\text { Fin de ciclo. }\end{array}$ & $\mathrm{X}$ & 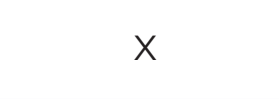 \\
\hline Abandono de los dioses. & $x$ & $x$ \\
\hline Muerte de los máximos gobernantes, cazonci y tlahtoani. & $x$ & $\mathrm{X}$ \\
\hline Pérdida del poder. & $x$ & $x$ \\
\hline Fin de los linajes de poder. & $x$ & $x$ \\
\hline Guerra de conquista. & $x$ & $x$ \\
\hline Destrucción de ciudades. & $\mathrm{X}$ & $\mathrm{X}$ \\
\hline Hambre, pobreza y enfermedad generalizada. & $x$ & $x$ \\
\hline Fin de las ceremonias y ritos tradicionales. & $\mathrm{X}$ & $x$ \\
\hline
\end{tabular}




\section{Sobre los presuntos modelos clásicos}

Aunque la discusión de los posibles modelos clásicos o cristianos de los relatos de la conquista aún requiere un análisis metódico y riguroso, por el momento se pueden adelantar algunas consideraciones a partir de un ejemplo específico. Se ha señalado que uno de los supuestos modelos más importantes para la elaboración del relato de los presagios de la conquista en la Historia general de Sahagún fueron los portentos de la caída de Jerusalén que se encuentran la Guerra de los judíos de Flavio Josefo (Rozat, 2010: passim; Thomas, 1994: 725, nota 17; Alcántara Rojas, 2019b: 110-111; Grunberg, 2019: 76). Al respecto se puede decir que un ejemplar del De antiquitatibus ac de beIlo judaico de Josefo se menciona en un inventario de 1574 de la biblioteca del Colegio Imperial de Santa Cruz en Tlatelolco (Mathes, 1982: 33), y por ello es posible que estuviera disponible para Sahagún y sus colaboradores al momento de la elaboración de Códice florentino.

Josefo refiere ocho señales de la caída de Jerusalén, a saber: primero, una señal celeste en forma de espada; segundo, un cometa que permaneció un año; tercero, una luz inexplicable que brilló a las tres de la mañana en el altar del Templo de Jerusalén; cuarto, una vaca que parió un cordero en medio del Templo; quinto, se abrió la puerta oriental del Templo a la media noche; sexto, al atardecer se vieron en el cielo carros y soldados que rodeaban las ciudades; séptimo, en la parte interior del Templo, durante la noche, se sintió una sacudida y se escuchó la voz de mucha gente que decía "marchémonos de aquí" y en octavo lugar, "más terrible aún que esto" fueron las constantes advertencias de Jesús, hijo de un campesino, que anunció una y otra vez durante cuatro años la destrucción de la ciudad diciendo, entre otras cosas: "iAy de ti, de nuevo, ciudad, pueblo y Templo!" (Josefo, 2007, L. VI; v. II: 293-298).

Al hacer el cotejo entre los portentos que aduce Josefo y los de la obra sahaguntina se revelan muchas y notables diferen- cias (cuadro 3), pues de los ocho presagios sólo en un caso hay correspondencia clara, se trata de la manifestación de un cometa. En otros tres casos hay una semejanza parcial, el primero es el de un astro parecido a una espada que se ha querido equiparar al mixpantli; sin embargo, la referencia de Josefo es muy escueta, sólo dice que se vio "un astro muy parecido a una espada", nada se dice de su tamaño ni su duración, ni si se movía, o si su orientación era vertical u horizontal, mientras que la descripción del mixpantli tiene múltiples detalles que no encajan con el texto de Josefo (vid supra); por ello, la identificación es infundada. El segundo caso de una semejanza parcial es la visión de carros y soldados en el aire con la visión de guerreros en el espejo del ave cuatézcatl; sin embargo, las diferencias son notables. Primero, el portento de Jerusalén es público, se muestra a la vista de todos, mientras que el tetzáhuit/ sahaguntino sólo es observado por Motecuhzoma, que se encuentra en el Tlillancalmécac, la institución educativa presidida por los sacerdotes de Cihuacóatl; segundo, la visión de los guerreros en el texto sahaguntino sólo es una parte de un tetzáhuit/ mucho más complejo con múltiples significados parciales que se entrelazan, por lo cual el tlahtoani recurre a los especialistas en la interpretación de las señales divinas, mientras que el portento referido por Josefo tiene un sentido obvio que no requiere de intérpretes. El tercer caso de semejanza parcial son las voces que escuchan algunos sacerdotes en el Templo interior de Jerusalén, donde después de una sacudida y un ruido se oye "la voz de una muchedumbre que decía: 'Marchémonos de aquí". Esto se ha equiparado con el llanto nocturno de Cihuacóatl. Nuevamente las diferencias son notables, el primero es un portento que sólo escuchan una vez algunos sacerdotes, el segundo es para toda la población y se escucha muchas veces; el primero es una voz colectiva que no se identifica, el segundo es una voz femenina individual plenamente identificada como una de las principales diosas madres del mundo náhuatl. 
Finalmente hay cuatro portentos sin ningún tipo de correspondencia: primero, la luz de madrugada en el altar del Templo; segundo, el cordero parido por una vaca en el Templo, la apertura de la puerta oriental del Templo y, tercero, los anuncios de Jesús que, como dice Josefo, es el portento "más terrible" y justamente por ello debería estar presente en el texto de los informantes de Sahagún del que se supone es modelo. Si se ve el conjunto de los presagios referidos en las obras de Josefo y de Sahagún, es evidente que hay muy pocas semejanzas, algunas francamente débiles, fragmentarias, vagas y superficiales, como para empeñarse en sostener que el texto de Josefo fue un modelo para los tetzáhuitl de los informantes de Sahagún. De tal suerte que puede afirmarse que la Guerra de los Judíos de Josefo no fue modelo ni referente para la elaboración de historia de la conquista recabada por Sahagún.

Por otra parte, si bien nadie ha postulado un vínculo entre la obra de Josefo y la Relación de Michoacán, a manera de ejercicio puede hacerse la comparación entre ambas obras con resultados similares. Sólo hay una débil correspondencia parcial en dos de ellos, el cometa, que en el caso de la Relación se habla de dos; en los anuncios proféticos de Jesús y en las palabras de Zuangua revelando el sentido de los portentos, con la significativa diferencia que Jesús se mueve fuera del círculo de poder y no es tomado en cuenta por los habitantes de Jerusalén, mientras que el cazonci es la máxima autoridad y funge más como intérprete que como un canal de comunicación con los dioses; en los otros presagios no hay ninguna semejanza.

\section{Cuadro 3 \\ Comparación de los presagios de la caída de Jerusalén con la caída de Tenochtitlan}

\begin{tabular}{|c|c|c|}
\hline Josefo & Libro XII Historia general & Comentario \\
\hline $\begin{array}{l}\text { 1. Un astro muy parecido } \\
\text { a una espada. }\end{array}$ & ¿Mixpantli? & $\begin{array}{l}\text { Semejanza parcial. La única } \\
\text { similitud es que son señales } \\
\text { celestes. }\end{array}$ \\
\hline $\begin{array}{l}\text { 2. Un cometa se ve durante } \\
\text { un año. }\end{array}$ & Cometa. & Semejanza general. \\
\hline $\begin{array}{l}\text { 3. A las } 3 \text { a.m. brilló durante } \\
\text { media hora una luz en el altar } \\
\text { del Templo. }\end{array}$ & Sin correspondencia. & \\
\hline $\begin{array}{l}\text { 4. Una vaca, que era llevada al } \\
\text { sacrificio, parió un cordero en } \\
\text { medio del Templo. }\end{array}$ & Sin correspondencia. & \\
\hline $\begin{array}{l}\text { 5. "A la seta hora de la noche } \\
\text { [24 h.] se abrió ella sola la } \\
\text { puerta oriental del Templo } \\
\text { exterior". }\end{array}$ & Sin correspondencia. & \\
\hline 6. Ejércitos en el cielo. & $\begin{array}{l}\text { Ave con espejo en la } \\
\text { cabeza, Motecuhzoma } \\
\text { ve en el espejo guerreros } \\
\text { montados en venados y el } \\
\text { mamalhuaztli. }\end{array}$ & $\begin{array}{l}\text { Semejanza parcial. Diferencias } \\
\text { notables, el primero es público, el } \\
\text { segundo sólo lo ve una persona } \\
\text { y es parte de un portento más } \\
\text { amplio. }\end{array}$ \\
\hline
\end{tabular}


Cuadro 3 (continuación)

\begin{tabular}{lll}
\hline \multicolumn{1}{c}{ Josefo } & Libro XII Historia general & \multicolumn{1}{c}{ Libro XII Historia general. } \\
\hline $\begin{array}{l}\text { 7. Los sacerdotes escuchan } \\
\text { por la noche en el Templo la } \\
\text { voz de una muchedumbre } \\
\text { que decía: "Marchémonos de } \\
\text { aquí". }\end{array}$ & $\begin{array}{l}\text { Cihuacóatl se oye por las } \\
\text { anónima una sola ocasión sin }\end{array}$ \\
$\begin{array}{lll}\text { identificar. Voz individual repetida } \\
\text { identificada con una diosa madre. }\end{array}$ \\
$\begin{array}{ll}\text { 8. Anuncios de Jesús } & \text { Falta el temblor y el ruido. } \\
\text { Localizado en el templo, en toda } \\
\text { la ciudad. }\end{array}$ \\
\hline
\end{tabular}

Fuente: elaboración propia.

\section{Conclusiones}

Ya desde 1959 Miguel León-Portilla advertía que los tetzáhuit/ o presagios de la conquista "reflejan, más que los hechos históricos mismos, el modo como los vieron e interpretaron los indios nahuas de diversas ciudades y procedencias" (León-Portilla, 2019: 4). En ese sentido, los tetzáhuit/ y presagios de la conquista son objetos privilegiados de estudio porque permiten acercarse a un recurso religioso, ideológico, simbólico e historiográfico para tratar de entender cómo las élites indígenas conceptualizaron no sólo el impacto de la conquista militar, sino también su cambio de rol y función social en la estructura novohispana al mediar el siglo XVI (Pastrana, 2004). Los ejemplos de estudio revelan cómo se gestó una continuidad de muchos moldes, temas, recursos e imágenes de gran antigüedad, que tuvieron que ser renovados, actualizados para ser útiles y funcionales historiográficamente en el contexto de mediados del siglo XVI. Es posible sostener un trasfondo cultural común a ambas narraciones de la conquista, el de la tradición religiosa mesoamericana. Los ejes que entrelazan el significado de los tetzáhuitl o presagios son la ruptura del tiempo, el fin de un ciclo celeste y uno terrestre, el abandono de los dioses, la pérdida del poder político, el fin de los linajes de la élite; la guerra y los males que trae consigo: la muerte, el hambre, la destrucción de ciudades y poblaciones.

También queda claro que, por lo menos en el caso de la obra de Flavio Josefo y la historia de la conquista tlatelolca compilada por Sahagún y su equipo, no son traslados de modelos clásicos, sino reajustes de los recursos la antigua tradición mesoamericana. Quienes planteen el uso de tales modelos deberán hacer algo más que sólo enumerar semejanzas superficiales.

En ese sentido, el análisis de la historiografía de tradición indígena abre la posibilidad de acercarse a creaciones y momentos específicos de un proceso social y conceptual extremadamente complejo, el de cómo las antiguas élites mesoamericanas trataron de rescatar la memoria de los grandes hechos de armas, de su gloria y su fama, al tiempo que la perdían y buscaban un acomodo, una nueva razón de ser en una sociedad colonial en transición que les debió generar tanta incertidumbre como a sus antepasados la llegada de los hombres de Castilla.

\section{Fuentes consultadas}

Aimi, Antonio (2009), La "verdadera" visión de los vencidos. La conquista de México en las fuentes aztecas, traducción de Celia Caballero Díaz, Alicante, Publicaciones de la Universidad de Alicante.

Alcántara Rojas, Berenice (2019a), "Signos del final de los tiempos. Los ocho presagios de la conquista en el Códice florentino", en Guilhem Olivier y Patricia Ledesma (coords.), Tetzáhuitı. Los presagios de la conquista de México, México, INAH. 
MIGUEL PASTRANA FLORES, PRESAGIOS, AUGURIOS Y PORTENTOS DE LAS CONQUISTAS DE MESOAMÉRICA

Alcántara Rojas, Berenice (2019b), "Signos del final de los tiempos. Los ocho presagios de la conquista en el Códice florentino", en Guilhem Olivier y Patricia Ledesma, (coords.), Tetzáhuitl. Los presagios de la conquista de México, México, INAH-Museo de Templo Mayor.

Alvarado Tezozómoc, Hernando de (1997), Crónica mexicana, edición de Gonzalo Díaz Migoyo y Germán Vázquez Chamoro, Madrid, Historia 16.

Bustamante García, Jesús (1990), Fray Bernardino de Sahagún. Una revisión crítica de los manuscritos y de su proceso de composición, México, UNAM-IIB.

Cortés, Hernán (1993), Cartas de relación, edición de Ángel Delgado Gómez, Madrid, Castalia.

Durán, Diego (1984), Historia de las Indias de la Nueva España e islas de la tierra firme, 2 v., edición de Ángel Ma. Garibay, México, Porrúa.

Echeverría García, Jaime (2018), "De monstruos y fenómenos naturales. Historia cíclica, presagios y destrucción de imperios en el Altiplano Central durante el Posclásico", Relaciones Estudios de Historia y Sociedad, núm. 153, pp. 293343.

Espejel Carbajal, Claudia (2004), "Voces, lugares y tiempos. Claves para comprender la Relación de Michoacán", tesis de doctorado en historia, El Colegio de Michoacán, Zamora.

Espinosa Pineda, Gabriel (1996), El embrujo del lago. El sistema lacustre de la cuenca de México en la cosmovisión mexica, México, UNAM-Instituto de Investigaciones Históricas.

Fernández-Armesto, Felipe (1992), “'Aztec' auguries and memories of the Conquest of México", en Renaissance Studies, v. 6, núms. 3-4, pp. 287-305.

Flavio Josefo (2007), La guerra de los judíos, 2 v., edición de Jesús Ma. Nieto Ibáñez, Madrid, Gredos.
García Quintana, Josefina (2003), "La Relación de Michoacán", en José Rubén Romero Galván (coord.), Historiografía mexicana de tradición indígena, México, UNAM-Instituto de Investigaciones Históricas.

Gaos, José (1967), De antropología e historiografía, México, Universidad Veracruzana.

Gilberti, Maturino (1559), Vocabulario en lengua de Mechoacán, México, <https:// bit.ly/3q79ydl>, diciembre de 2020.

Graulich, Michel (2014), Moctezuma. Apogeo y caída del imperio azteca, trad. de Tessa Brisac, México, Era/INAH.

Graulich, Michel (1992), "Los presagios de la caída del imperio azteca", en Cuicuilco, México, ENAH, julio-diciembre 1992, núms. 31-32, pp. 93-100.

Grunberg, Bernard (2019), "Signos y profecías en el mundo de los conquistadores", trad. de Rosario Acosta Nivea, en Patricia Ledesma Bouchan y Guilhem Olivier (coords.), Los presagios de la conquista de México. Tetzáhuitl, México, Raíces / Arqueología Mexicana, edición especial 89, pp. 72-80.

Iglesia, Ramón (1986), El hombre Colón y otros ensayos, introducción de Álvaro Matute, México, FCE.

Johansson, Patrick (2013), "Presagios del fin de un mundo en textos proféticos nahuas", Estudios de Cultura Náhuatl, México, UNAM-IIH, v. 45, enero-junio 2013, pp. 69-147.

León-Portilla, Miguel (2019), Visión de los vencidos. Relaciones indigenas de la Conquista, edición conmemorativa, introducción, selección y notas de Miguel León-Portilla, traducción de Ángel María Garibay y Miguel León-Portilla, México, UNAM.

León-Portilla, Miguel (2018), La filosofía náhuatl estudiada en sus fuentes, México, UNAM-Instituto de Investigaciones Históricas. 
León-Portilla, Miguel (1992), "Las profecías del encuentro. Una aproximación mesoamericana del otro", en Miguel León-Portilla (ed.), De palabra y obra en el Nuevo Mundo 2. Encuentros interétnicos, México, Siglo XXI.

León-Portilla, Miguel (1991), "Profecías y portentos en vísperas de la conquista", en María Luisa Rivera et al., Ideas y presagios del descubrimiento de América, México, FCE.

López Austin, Alfredo (2019), "¿Qué es un augurio?", en Guilhem Olivier y Patricia Ledesma (coords.), Tetzáhuitl. Los presagios de la conquista de México, México, INAH.

López Austin, Alfredo (2015), Las razones del mito. La cosmovisión mesoamericana, México, ERA.

López Serralengue, Delfina Esmeralda (1965), La nobleza indigena de Pátzcuaro en la época virreinal, México, UNAM.

Magaloni Kerpel, Diana (2016), Albores de la conquista, México, Artes de México/ Secretaría de Cultura.

Magaloni Kerpel, Diana (2003), "Imágenes de la conquista de México en los códices del siglo XVI. Una lectura de su contenido simbólico", Anales del Instituto de Investigaciones Estéticas, México, UNAM-IIE, núm. 82, pp. 5-45.

Martínez González, Roberto (2013), Cuiripu: cuerpo y persona entre los antiguos p’urhépecha de Michoacán, México, UNAM-Instituto de Investigaciones Históricas.

Martínez, José Luis (1990), Hernán Cortés, México, FCE.

Mathes, Miguel (1982), Santa Cruz de Tlatelolco: La primera biblioteca académica de las américas, presentación de Miguel León-Portilla, México, Secretaría de Relaciones Exteriores.
Mendieta, Gerónimo de (1980), Historia eclesiástica Indiana, edición facsimilar, 2a edición, edición facsimilar, edición, noticias e índice por Joaquín García Icazbalceta, México, Porrúa.

Molina, Alonso de (2014), Diccionario náhuatl español basado en los diccionarios de Alonso de Molina con el náhuatl normalizado y el español modernizado, edición de Marc Thouvenot, México, UNAM-IIH.

Molina, Alonso de (1977), Vocabulario en lengua castellana y mexicana y mexicana y castellana, $2^{\text {a }}$ edición, edición facsimilar, estudio preliminar, de Miguel León-Portilla, México, Porrúa.

Monzón, Cristina (2005), "Los principales dioses tarascos: un ensayo de análisis etimológico en la cosmología tarasca", Relaciones. Estudios de Historia y Sociedad, otoño 2005, 26 (104), pp. 135168.

Morales Campos, Arturo y González Vidal, Juan Carlos (2017), "La visión de un nuevo estado de cosas en la Relación de Michoacán", en Legajos, México, AGN, Número 12.

Muñoz Camargo, Diego (2000), Descripción de la ciudad y provincia de Tlaxcala, edición de René Acuña, San Luis Potosí, El Colegio de San Luis.

Nicolau D'Olwer, Luis (1952), Fray Bernardino de Sahagún (1499-1590), México, Instituto Panamericano de Geografía e Historia.

O'Gorman, Edmundo (2009), Imprevisibles historias. En torno a la obra y legado de Edmundo O'Gorman, estudio preliminar y selección de Eugenia Meyer, México, FCE/UNAM-FFyL.

O’Gorman, Edmundo (1999), Historiología: teoría y práctica, est. int. y selección de Álvaro Matute, México, UNAM.

Olivier, Guilhem (2019a), "Tetzáhuitl: Ios presagios de la conquista de México", en Guilhem Olivier y Patricia Ledesma 
MIGUEL PASTRANA FLORES, PRESAGIOS, AUGURIOS Y PORTENTOS DE LAS CONQUISTAS DE MESOAMÉRICA

(coords.), Tetzáhuitl. Los presagios de la conquista de México, México, INAH.

Olivier, Guilhem (2019b) "Controlar el futuro e integrar al otro: los presagios de conquista de México", en Guilhem Olivier y Patricia Ledesma (coords.), Tetzáhuitl. Los presagios de la conquista de México, México, INAH.

Olmos, Andrés de (2002), Arte de la lengua mexicana, edición facsimilar, edición, estudio introductorio, transliteración y notas de Ascensión Hernández y Miguel León-Portilla, México, UNAM-Instituto de Investigaciones Históricas.

Pastrana Flores, Miguel (próximamente), "Aurora y ocaso de un proyecto. La Relación de la conquista de esta Nueva España como la contaron los soldados indios que se hallaron presentes de 1585 en el contexto de la vida y obra de fray Bernardino de Sahagún", México, UNAM.

Pastrana Flores, Miguel (2020), "La entrega del poder de Motecuhzoma. Una propuesta crítica", en Estudios de Historia Novohispana, núm. 62, enero-junio 2020, México, UNAM-Instituto de Investigaciones Históricas, pp.

Pastrana Flores, Miguel (2019a), "Una historiografía en busca de historiadores. El estudio de la historiografía de tradición indígena", en HistoriAgenda, 4ª época, núm. 38: octubre de 2018-marzo de 2019, México, UNAM-CCH, pp. 5-13, <https://bit.ly/2MSRK7k>, diciembre de 2020 .

Pastrana Flores, Miguel (2019b), "Tillancalqui, 'El señor de la casa de la negrura'. Acercamiento a un alto dignatario mexica", en Alonso Guerrero Galván y Luis René Guerrero Galván (coords.), Construcción histórico-jurídica del derecho prehispánico y su transformación ante el derecho indiano, México, UNAM-IIJ.

Pastrana Flores, Miguel (2015), "Las cosas mal dichas y mal calladas. Las diferencias entre la primera y la segunda ver- siones de la Relación de la conquista de Nueva España de fray Bernardino de Sahagún", en Martín Ríos (ed.), El mundo de los conquistadores. La península Ibérica en la Edad Media y su proyección en la conquista de América, Madrid, Silex/UNAM-Instituto de Investigaciones Históricas.

Pastrana Flores, Miguel (2014), "La idea de tetzáhuitl en la historiografía novohispana. De la tradición náhuatl a la Ilustración. Comentarios preliminares", Estudios de Cultura Náhuatl, 47, México, UNAM-Instituto de Investigaciones Históricas, pp. 237-252.

Pastrana Flores, Miguel (2011), "Historiografía de tradición indígena", en Historia general ilustrada del Estado de México, vol. II, México, Gobierno del Estado de México/El Colegio Mexiquense A.C./ Poder Judicial del Estado de México/ LVII Legislatura del Estado de México, pp. 55-85.

Pastrana Flores, Miguel (2004), Historias de la Conquista. Aspectos de la historiografía de tradición náhuatl, México, UNAM-Instituto de Investigaciones Históricas.

Pastrana Flores, Miguel (1999), "Los presagios de la conquista como forma de conciencia histórica", en Estudios michoacanos, v. VIII, Zamora, El Colegio de Michoacán/Instituto Michoacano de Cultura, pp. 127-142.

Popol Wuj (2012), edición de Sam Colop, Guatemala, F\&G Editores.

Relación de Michoacán. Relaçión de las ceremonias y rrictos y población y governaçión de los yndios de la provinçia de Mechoacán (2001), facsímil, Madrid, Testimonio.

Relación de Michoacán (2011), presentación de Rafael Diego-Fernández, estudio introductorio de Jean-Marie G. Le Clézio, [paleografía y notas de Clotilde Martínez Ibáñez y Carmen Molina Ruiz], Guadalajara, El Colegio de Michoacán. 
Relación de Michoacán (1989), edición de Leoncio Cabrero, Madrid, Historia 16.

Romero Galván, José Rubén (2003), "Introducción", en José Rubén Romero Galván (coord.), Historiografía mexicana de tradición indigena, México, UNAM-Instituto de Investigaciones Históricas.

Roskamp, Hans (1998), La historiografía indigena de Michoacán: El Lienzo de Jucutacato y los Títulos de Carapan, Leiden, Leiden University: Research School CNWS.

Rozat Dupeyron, Guy (2010), Indios imaginarios e indios reales en los relatos de la conquista de México, México, Universidad Veracruzana.

Ruiz de Alarcón, Hernando (1988), Tratado de las supersticiones y costumbres gentilicas que hoy viven entre los indios naturales desta Nueva España, edición de Ma. Elena de la Garza, México, SEP.

Sahagún, Bernardino de (2000), Historia general de las cosas de Nueva España, edición de Alfredo López Austin y Josefina García Quintana, 3 v., México, Conaculta.

Sahagún, Bernardino de (1993), Adiciones, Apéndice a la Apostilla y Ejercicio cotidiano, edición facsimilar, edición, paleografía, traducción y notas de Artuh J. O. Anderson, México, UNAM-Instituto de Investigaciones Históricas.

Sahagún, Bernardino de (1990), Historia general de las cosas de Nueva España, 2 v., edición de Juan Carlos Temprano, Madrid, Historia 16.

Sahagún, Bernardino de (1986), Coloquios y doctrina cristiana con que los doce frailes de San Francisco, enviados por el papa Adriano VI y por el emperador Carlos V, convirtieron a los indios de la Nueva España. En lengua mexicana y castellana, edición de Miguel León-Portilla, México, UNAM/Fundación de Investigaciones Sociales.
Sahagún, Bernardino de (1979), Códice florentino. Manuscrito 218-20 de la Colección Palatina de la Biblioteca Medicea Laurenciana, edición facsimilar, 3 v., México, $A G N$.

Sahagún, Bernardino de (1969), Augurios y abusiones, introducción, traducción y notas de Alfredo López Austin, México, UNAM-Instituto de Investigaciones Históricas.

Sahagún, Bernardino de (1956), "Libro doce. En él se dice cómo se hizo la guerra en esta ciudad de México", en Bernardino de Sahagún, Historia general de las cosas de Nueva España, 4 v., edición, traducción y notas de Ángel María Garibay, México, Porrúa.

Tena, Rafael (edición, paleografía y traducciones) (2002), "Historia de los mexicanos por sus pinturas", en Mitos e historias de los antiguos nahuas, México, Conaculta.

Thomas, Hugh (1994), La conquista de México, traducción de Víctor Alba, México, Patria.

Torquemada, Juan de (1975-77), Monarquía indiana. De los veinte y un libros rituales y monarquía indiana, con el origen y querras de los indios occidentales, de sus poblazones, descubrimiento, conquista, conversión y otras cosas maravillosas de la mesma tierra, 7 v., edición de Miguel León-Portilla, et al., México, UNAM-IIH.

Velázquez Gallardo, Pablo (1978), Diccionario de la lengua phorhepecha. Español-phorhepecha, phorhepecha-español, México, FCE.

Warren, J. Benedict (2001), "El autor, fray Jerónimo de Alcalá", en Armando Mauricio Escobar Olmedo et al., Relación de Michoacán [estudios], Madrid, Testimonio.

Warren, J. Benedict (1989), La conquista de Michoacán 1521-1530, $2^{a}$ edición, traducción de Agustín García Alcaraz, Morelia, Fimax Publicistas. 
Recibido: 8 de enero de 2021. Reenviado: 8 de enero de 2021. Aceptado: 26 de enero de 2021.

\section{Miguel Pastrana Flores}

Doctor en Historia por la Facultad de Filosofía y Letras (FFyL) de la Universidad Nacional Autónoma de México (UNAM). Es investigador del Instituto de Investigaciones Históricas $(\mathrm{IIH})$ de la UNAM; es profesor de la Licenciatura en Historia de la FFyL de la UNAM; Coordinador del Programa de Maestría en Doctorado en Historia de la UNAM. Sus principales líneas de investigación son la historiografía de tradición indígena y las instituciones religiosas mesoamericanas. Es autor de los libros Arte tarasco (Conaculta, 1999); Historias de la conquista. Aspectos de la historiografía de tradición náhuatl (UNAM, 2004), Entre los hombres y los dioses. Acercamiento al sacerdocio de calpulli entre los antiguos nahuas (UNAM, 2008), Teotihuacanos, toltecas y tarascos (Nostra Ediciones/Conaculta, 2013). Con Rosa Camelo editó el libro La experiencia historiográfica. VIII Coloquio de Análisis historiográfico (UNAM, 2009); con María Elena Vega Villalobos editó el libro El gobernante en Mesoamérica. Representaciones y discursos del poder (UNAM, 2018). Igualmente, ha publicado diversos capítulos de libros entre los que pueden mencionarse: "Historiografía de tradición indígena” en Historia general ilustrada del Estado de México (El Colegio Mexiquense A.C., 2011), "El corazón del hogar. Ensayo sobre la educación femenina entre los antiguos nahuas", en Proyectos de educación en México: perspectivas históricas (UNAM, 2014), "La caída de Tula en el Códice florentino. Escritura y rescate de la memoria náhuatl de un desastre en un contexto catastrófico", en L'Élégie du desastre. De l'archive á l'historire (Éditiones Hispaniques / UNAM, 2019) y "Tlillancalqui, 'el señor de la casa de la negrura'. Acercamiento a un alto dignatario mexica", en Construcción histórico-jurídica del derecho prehispánico y su transformación ante el derecho indiano, (UNAM, 2019). Entre sus publicaciones más recientes se encuentran, como autor: "La entrega del poder de Motecuhzoma. Una propuesta crítica”, Estudios de Historia Novohispana, núm. 62, México, UNAM, pp. 111-144 (2020) y "Una historiografía en busca de historiadores. El estudio de la historiografía de tradición indígena", HistoriAgenda, núm. 38, México, UNAM (2019). 